\title{
ニューラルネットワークによる風景の探査
}

\section{Search Systems for Landscape by Neural Network.}

市原恒一 ${ }^{*}$ 豊川勝生 ${ }^{* *}$ 田中利美 ${ }^{* *}$ 澤口勇雄 ${ }^{* *}$

Kouichi ICHIHARA Katsumi TOYOKAWA Toshimi TANAKA Isao SAWAGUCHI

摘要 : 森林公園や国立公園の選択に用いることができる風景の探查システムをニューラルネットワー クにより構築した。はじめに, 12 枚の秋の森林風景写真について 10 対の形容詞対による景観評価試 験を行った。つぎに, この結果を入カとして, 評価画像を教師データとした教師付き学習方式を遺伝 的アルゴリズムにより構筑した。また, 教師データを風景の構成要素としたシステムも構筑した。遺 伝的アルゴリズムを用いた場合, 探查に各種の制約条件を付けることができること, およびネットワー クの構造も同時に決定することができるため, 正解率が $72 \%$ 以上なり, 正解率が高いシステムを 構築することができた。

\section{1.はじめに}

近年, アウトドアライフを楽しむため森林公園や国立公園を利 用する人が増加している。一般に, 公園の施設や風景の案内など にはパンフレットが使われている。公園を利用する人はそれを見 て, 訪れる公園を決定すると考えられる。すなわち, 公園側の一 方的な説明を基に, 利用者自身により決定が行われている。しか し, 公園の内容および利用者の趣向は多種多様であるため, パン フレットですべてを説明することには限界があると考えられる。

筆者らは, 多様な公園利用者の増加に対応するため, 来訪する 公園の決定支援システムの構築を行っている。すなわち, 利用者 の公園に対する趣向を入力することにより, 多くの公園の中から 要求に合致した公園を紹介するシステムについて検討している。 旅行案内所やビジターセンターにおいて，本システムを設置すれ ば，より配慮が行き届いた公園の選択が可能になると考えられる 本報告では, 上記システムの 1 部分である風景の探査システム をニューラルネットワークにより構築した。この探査システムは 風景に対するイメージから風景または風景の構成要素を探查する あのである。

通常, 教師付きニューラルネットワークはバックプロパゲーショ ンにより構築される ${ }^{1)}$ 。本研究では, ネットワークのウエイトの 決定と同時にネットワーク構造決定および制約条件の付加を行う ことができる遺伝的アルゴリズムによりシステムを構築した。こ のシステムを秋の森林風景の探查に適用し, 正解率などについて 検討を加えた。

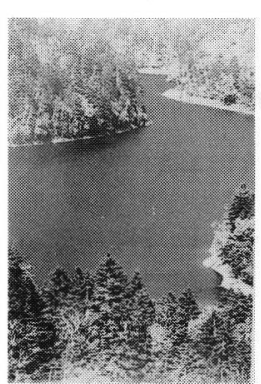

風景 1

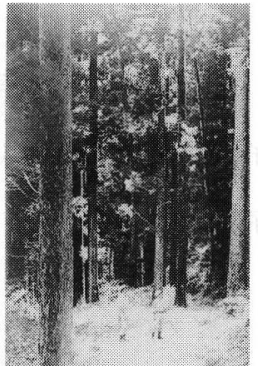

風景 2

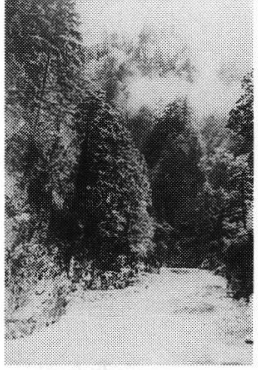

風景 3

2. ニューラルネットワークの構築

教師付きニューラルットワークのウエイトを遺伝的アルゴリズ ムにより求めた。

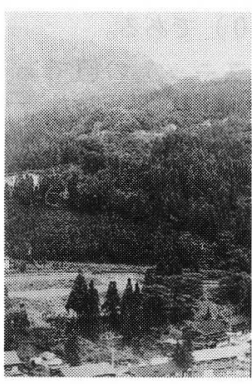

風景 4

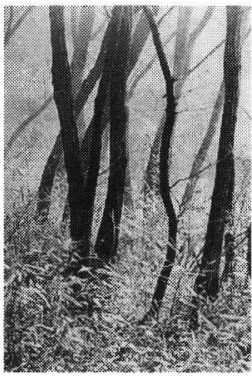

風景 7

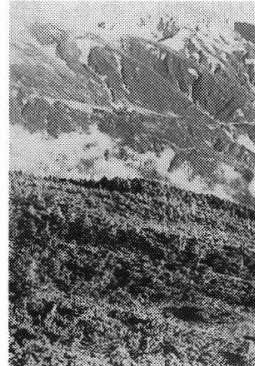

風景 10

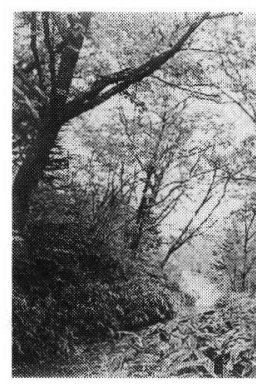

風景 5

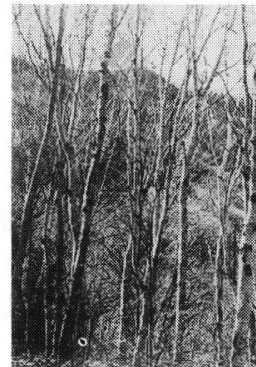

風景 8

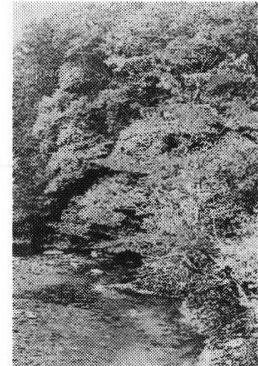

風景 11

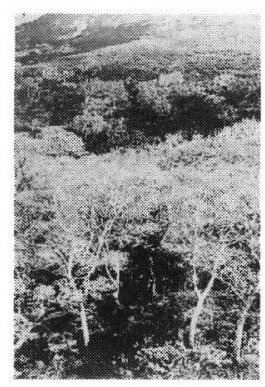

風景 6

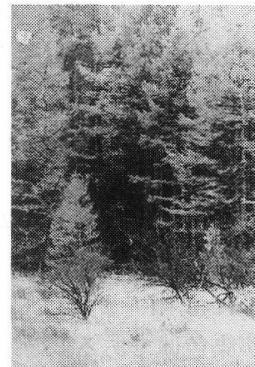

風景 9

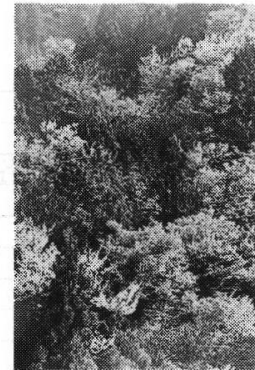

風景 12

*筑波大学農林工学系 ${ }^{* *}$ 農林水産省森林総合研究所 


\section{(1) 景観評価試験}

風景とそこから受けるイメージとの関係を求めるため, 景観評 価試験を行った。供試画像は, 11 枚の秋と 1 枚の春の森林風景 である。この結果をニューラルネットワークの入力とした。風景 の概要と形容詞対を表 -1 と 2 , 被験者の概要を表 -3 に示す。 被験者は, 森林総合研究所の職員と筑波大学の学生である。

(2) ニューラルネットワーク

ニューラルネットワークとは, 神経回路網を模倣した人工知能 の一種で, 複数個の入出力ユニット（ノード）と中間ユニットお よびこれらを接続する経路からなる。教師付き学習とは, ニュー ラルネットワークの入力側に事例デー夕を与えると同時に，この 事例デー夕に応じてネットワークが出力すべき值（教師デー夕） あ一緒に与えて, ニューラルネットワークが入力データに対して 適切なデー夕を出力するように自己変化させようというあのであ る。一般に, 入力の数值は, ” 1 ”または” 0 ”の数値を用いる。

各ユニットの值は, 1 歩前のユニットの值に経路のウエイト （シナプス結合荷重）を乗じで，すべて加えた数值である。y（i, $\mathrm{j})$ を第 $\mathrm{i}$ 層の第 $\mathrm{j}$ 番ユニットの值, $\mathrm{a}(\mathrm{i}, \mathrm{j}, \mathrm{k}, \mathrm{l})$ を第 $\mathrm{i}$ 層の第 $\mathrm{j}$ 番 ユニットと第 $\mathrm{k}$ 層の第 1 番ユニット間のウエイトとすれば，(1) 式が成り立つ。

$$
y(i, j)=\sum_{k, 1} a(i, j, k, 1) \cdot y(k, 1) \quad(i>k)
$$

ただし，y $(0, j)$ は入力ユニットの值（1 or 0$)$ である。

中間層の数を $\mathrm{m}$ とすれば $\mathrm{y}(\mathrm{m}+1, \mathrm{j})$ は出力ユニットの值であ る。 $\mathrm{y}(\mathrm{m}+1, \mathrm{j}) を(2)$ 式のシグモイド関数により $0 \sim 1$ の数値に 変換した值 $\mathrm{x}(\mathrm{j})$ を出力とする。

$$
x(j)=1 /\{1+\exp (0.5-y(m+1, j))\}
$$

中間層においてあシグモイド関数による変換を行う場合もある がここでは出力層だけ変換した。

\section{（3）遺伝的アルゴリズム}

遺伝的アルゴリズムとは，システムのパラメータで構成される ベクトルを仮想染色体として, 進化シミュレーションにより, シ ステムの最適値を探査するアルゴリズムである ${ }^{2,3)}$ 。遺伝的アルゴ リズムは, 主に数学モデルを構築できないシステムの最適パラメー 夕の探查問題などに利用される。本研究ではニューラルネットワー クのウエイトと構造（経路の配置）の決定に使用した。

遺伝的アルゴリズムとは, 図一 1 に示す進化シミュレーション を繰り返し行ない，最適值を探査するアルゴリズムである。遺伝 子には” 1 ”または” 0 ”の数値をあてる。遺伝子が連結したもの が染色体である。

遺伝的アルゴリズムの特徵の 1 つは, 染色体を集団として取り 扱うことである。初期生物集団とは, 一様乱数により選択された 染色体のグループで, 進化シミュレーションの初期值である。評

\begin{tabular}{|c|c|}
\hline & 表 - 1 風景の概要 \\
\hline 番号 & 風量 \\
\hline 1 & 濃い水色の湖の周辺の森林は混交林で広葉樹は紅葉している. \\
\hline 2 & スキの高木林の林内景観である. 中央部に道路がある. \\
\hline 3 & 降雨直後の渓谷, 濁流が流れ，雲がある.岩上に針葉樹がある. \\
\hline 4 & 針葉樹の人工林に林道ののり面が見える. 黄色の田と農家がある. \\
\hline 5 & 紅葉したカエテの下に歩道が通る. \\
\hline 6 & シラカバの黄葉, 鼓方には緑の山腹が見える. \\
\hline 7 & 落葉したコナラの2次林の林内景観. \\
\hline 8 & 落枼したダケカンバの林内景観. \\
\hline 9 & カラマツの黄葉. \\
\hline 10 & 山岳地帯のハイマツ \\
\hline 11 & 紅葉した力エデの下に水色の渓流が流れる. \\
\hline 12 & 針広湿交林内の桜力咲いている。 \\
\hline
\end{tabular}

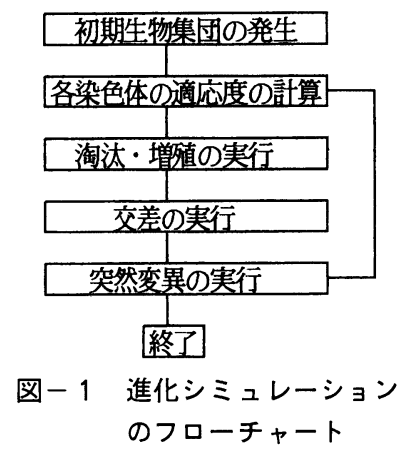

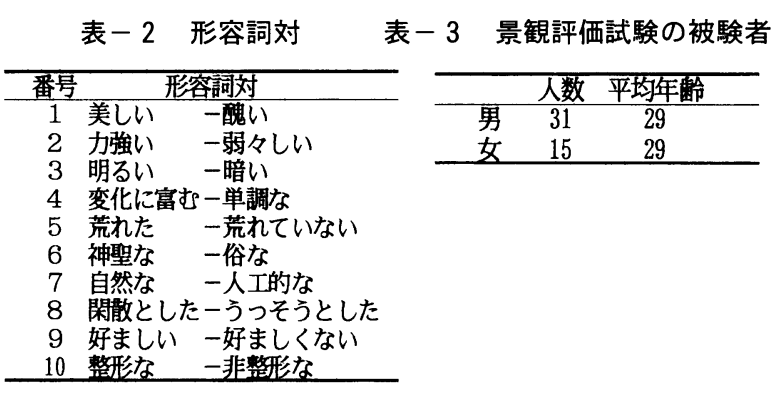

価とは, 染色体の情報をパラメータの值に変換して, システムの 評価值を求めることである。交差 (1 点交差) とは，2 本の染色 体を同じ位置で切断し，片方を互いに交換する操作である。突然 変異とは, 染色体の一部分の遺伝子の記号を反転した新たな遺伝 子を生成する操作で, 1 本の染色体で突然変異が生じる遺伝子の 数は突然变異率により決定される。交差と突然変異の概要を図一 2,3 に図示する。淘汰とは，初期生物集団，交差または笑然変 異により生成された染色体およびその親のグループからその後の 進化シミュレーションに供する染色体を取捨選択する操作である 般に，この選択確率は評価值に比例した值とする。

(4) 教師データとして風景を与えたシステム (システムA)

システムの入力ユニットは, 景観評価試験における形容詞対の 評価尺度に対応している。10 個の形容詞対について, それぞれ 5 段階評価尺度により評価したため, 入力ユニット数は 50 であ る。被験者がチェックした各形容詞対の評価尺度の入力を” 1 ”, その他の尺度の入力を” 0"とした。中間層のユニットは, 形容 詞対に対応しており, 10 個ある。入力ー中間層間の経路は, 対 応する形容詞対の間だけ接続がある。出力のユニットは, 風景に 対応しており, 供試風景に” 1 ”, それ以外の風景に” 0 ”を出力

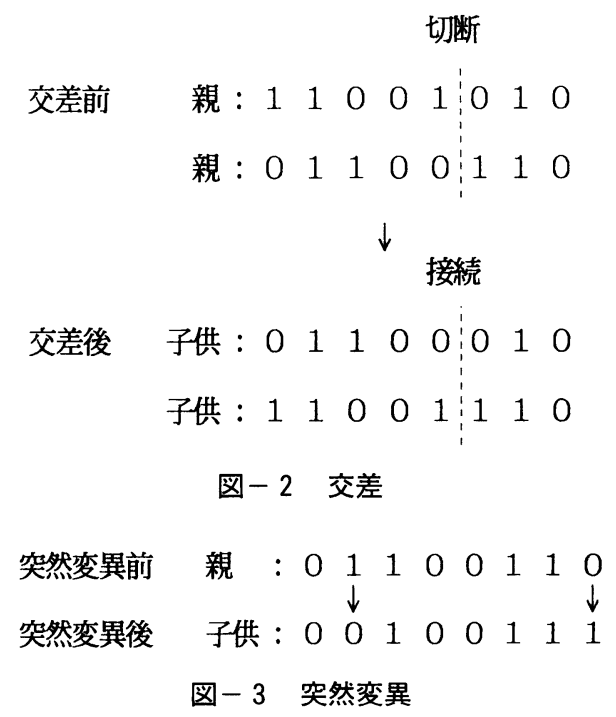


する。中間層一出力層の経路はすべてのユニット間に接続がある。 経路数は入力層一中間層が 50 , 中間層一出力層が 120 である。 ネットワークを図ー 4 に示す。通常のシステムでは, 中間層の 1 個のユニットはすべての入力ユニットと接続しているが, ここで は, 入力として, 同じ形容詞対に属する評価尺度がグループを形 成しているため, 中間層はそのグループをまとめるユニットとし た。

経路のウエイトを遺伝的アルゴリズムにより求めた。染色体を (3)式とする。

$$
\{\mathrm{Z}(1), \cdots, \mathrm{Z}(\mathrm{K}), \mathrm{W}(1), \cdots, \mathrm{W}(\mathrm{N})\}
$$

ただし， Nはウエイトの数 $(170), \mathrm{K}$ は定数 $(8), \mathrm{Z}(\mathrm{J})$ は後述す る b を決定するための遺伝子である（Z $(J)=0$ or 1$) 。$ W (I) は I 番目のウエイトを表すべクトルで，（4)式による。

$$
\mathrm{W}(\mathrm{I})=\left\{\mathrm{Y}(\mathrm{I}), \mathrm{X}(\mathrm{I}, 1), \mathrm{X}(\mathrm{I}, 2), \begin{array}{l}
\cdots, \mathrm{X}(\mathrm{I}, \mathrm{K})\} \\
(\mathrm{I}=1,2, \quad \cdots, \mathrm{N})
\end{array}\right.
$$

ただし， $\mathrm{X}(\mathrm{I}, \mathrm{J})=0$ or $1 ， \mathrm{Y}(\mathrm{I})$ はウエイトの符号を定める ための遺伝子である（Y (I)=0 or 1$) 。$

I 番目のウエイト $\mathrm{a}$ (I)は(5)式から求めることができる。

$$
a(I)=b(-1)^{Y(I)} \sum_{J=1}^{K} 2^{J-1} X(I, J)
$$

ただし， b = C $\sum_{J=1}^{K} 2^{\mathrm{J}-1} Z(J)$, 通常, bを定数とするが, ここ では変数とした。Cは定数(本研究では， $\mathrm{C}=0.0004) 。$

ウエイト a (I)の添え字 Iを(1)式の a (i,j,k, l)の添え字に変換 して(1)式から出力ユニットの值を計算した。遺伝的アルゴリズ ムにより, 次式のQを最小にするウエイトの組合わせを探査した。

$$
\mathrm{Q}=1 / \mathrm{r}_{0}+1 / \mathrm{r}_{1}
$$

ただし， $\mathrm{r}_{0}$ および $\mathrm{r}_{1}$ は，それぞれ正解が” 0 ”および” 1 ”と なる出力ユニットの正解率である。

突然変異率は, 初期值を $0.1 ， 1$ ステップごとに $1 / 5000$ だけ 減少する变数とした。通常, 評価値が設定値を超えた時点で計算 を終了するが, 本計算では, 設定値を特定できなかったので, 交 差と突然変異をそれぞれ 500 回繰り返して, 計算を終了した。

\section{(5)教師データとして風景構成要素を与えたシステム}

(システム $\mathrm{B}$ )

出力ユニットは, 表一 4 に示す 14 個の風景の構成要素である。 システムBのネットワークは, システムAのネットワークと図ー 5 の入力と出力を結ぶ経路を合成した構造である。ただし, すべ ての人力と出力を結ぶ経路が接続されているとは限らず, 接続の 有無は遺伝的アルゴリズムにより決定した。想定した経路の数は 入力層一中間層が 50 , 中間層－出力層が 140 , 入力層一出力層が 700 であるため, 求めるべきウエイトの数は 890 である。(5)式 $(\mathrm{K}=8)$ でウエイトを表すとすれば，1染色体に 8010 のディメ ンジョンが必要である。さらに遺伝的アルゴリズムでは, 染色体 を集団で扱うため，これの整数倍のディメンジョンが必要である ここでは 200 個体を 1 度に処理するとして, $200 \times 8010=1,602,000$ 以上の整数のディメンジョンを要する。パーソナルコンピュータ では，容量が不足する。

そこで，ディメンジョンを節約するため， 2 本の染色体を想定 した。1 本は長さ 890 の実数染色体 $\mathrm{T}$ (I) $\{0.0 \leqq \mathrm{~T}(\mathrm{I}) \leqq 1.0\}$ （ I = $1, \cdots, 890)$ である。他の 1 本は長さ 1590 の整数染色体 $\mathrm{L}(\mathrm{J})(\mathrm{J}=$ $1, \cdots, 1590)$ である。実数染色体の遺伝子の值に定数をかけた值

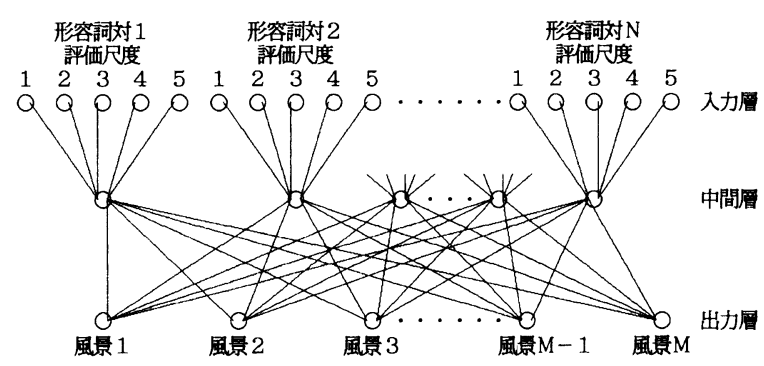

\begin{tabular}{|c|c|c|c|c|c|c|c|c|c|c|c|c|}
\hline \multirow[t]{2}{*}{ 構 成 } & \multicolumn{12}{|c|}{ 画像番号 } \\
\hline & 1 & 2 & 3 & 4 & 5 & 6 & 7 & 8 & 9 & 10 & 11 & 12 \\
\hline 広葉樹 & 1 & 0 & 0 & 0 & 1 & 1 & 1 & 1 & 0 & 0 & 1 & 1 \\
\hline 針葉樹 & 1 & 1 & 1 & 1 & 0 & 0 & 0 & 0 & 1 & 1 & 0 & 1 \\
\hline 葉 紅・黄色 & 1 & 0 & 0 & 0 & 1 & 1 & 1 & 0 & 1 & 0 & 1 & 1 \\
\hline 葉 緑色 & 1 & 1 & 1 & 1 & 0 & 0 & 0 & 0 & 0 & 1 & 1 & 1 \\
\hline 水の有無 & 1 & 0 & 1 & 0 & 0 & 0 & 0 & 0 & 0 & 0 & 1 & 0 \\
\hline 水 水色 & 1 & 0 & 0 & 0 & 0 & 0 & 0 & 0 & 0 & 0 & 1 & 0 \\
\hline 水 茶色 & 0 & 0 & 1 & 0 & 0 & 0 & 0 & 0 & 0 & 0 & 0 & 0 \\
\hline 近景 & 0 & 1 & 1 & 0 & 1 & 1 & 1 & 1 & 1 & 0 & 1 & 1 \\
\hline 遠景 & 1 & 0 & 1 & 1 & 0 & 1 & 0 & 1 & 0 & 1 & 0 & 0 \\
\hline 林内景観 & 0 & 1 & 0 & 0 & 1 & 0 & 1 & 1 & 0 & 0 & 0 & 0 \\
\hline 林外景観 & 1 & 0 & 1 & 1 & 0 & 0 & 0 & 0 & 1 & 1 & 1 & 1 \\
\hline 道路の有無 & 0 & 1 & 0 & 1 & 1 & 0 & 0 & 0 & 0 & 0 & 0 & 0 \\
\hline 曲線道路 & 0 & 1 & 0 & 0 & 1 & 0 & 0 & 0 & 0 & 0 & 0 & 0 \\
\hline 直線道路 & 0 & 0 & 0 & 1 & 0 & 0 & 0 & 0 & 0 & 0 & 0 & 0 \\
\hline
\end{tabular}

図ー 4 システムAのネットワーク $(M=12, N=10)$

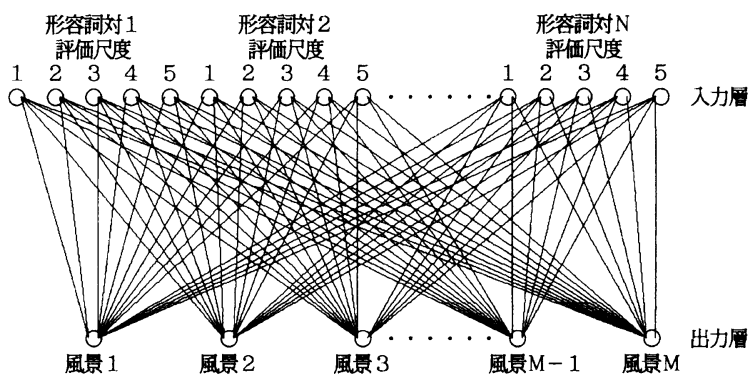

図－５システムBの入力層ー出力層間のネットワーク（ $M=14 ， N=10 ）$

表 -4 風景の構成（システムBにおける出力）

がウエイトの絶対値である。整数染色体において, L (1)〜 L (700) および $\mathrm{L}(701) \sim \mathrm{L}(1400)$ は, それぞれ入力層一出力層のウエイ トの符号および経路の存在の有無を示し, L (1401)～L (1590)は 入力層一中間層および中間層一出力層のウエイトの符号を表す。 入力層一出力層間のウエイト $\mathrm{a}(\mathrm{I})$ は $(7,8)$ 式から, 入力層一中間 層と中間層一出力層のウエイトは(7)式から得る。

$$
\begin{array}{lr}
\mathrm{a}(\mathrm{I})=\mathrm{C}(-1)^{\mathrm{L}(\mathrm{I})} \mathrm{T}(\mathrm{I}) & \{\mathrm{L}(\mathrm{H})=1\} \\
\mathrm{a}(\mathrm{I})=0 & \{\mathrm{~L}(\mathrm{H})=0\} \\
& (\mathrm{I}=1,2, \cdots, 700, \mathrm{H}=\mathrm{I}+700)
\end{array}
$$

ただし，Cは定数（本研究では， C = 10)， L (I)=0 or 1 ，

交差と突然变異は，2本の染色体でそれぞれ独立に行った。実 数染色体の突然变異は, $0 \sim 1$ の一様乱数を発生して遺伝子の值 を変え, 交差は整数遺伝子と同じ一点交差である。突然変率とシ ステムの評価法などは, システム $\mathrm{A}$ と同じである。交差と突然変 異をそれぞれ 500 回繰り返した。 


\section{3、結果および考察}

システム $\mathrm{A}$ と B の結果は，表一 5 のとおりである。上記のとお り， $\mathrm{r}_{0}$ および $\mathrm{r}$ ，とは正解が” 0 ”および” 1 ”となる出力ユニッ トの正解率である。システムAでは，(5)式における係数 $\mathrm{b}$ は $\mathrm{b}=$ 0.0952 であった。システムBでは，入力層一出力層の 700 のウ エイトの内 259 が 0 であった。

景観評価のように個人の感覚を探査するシステムでは，デー夕 のばらつきが大きい。このようなシステムにおいて, 表一 5 に示 すように正解率が 0.72 以上となっため，これらはおおむ描足 できる結果である。システムBのネットワークは, システムAの ネットワークに入力層一出力層の経路を加えたものであるため, システムAに比べて複雑である。しかし, 両システムの正解率は, ほぼ等しい。すなわち入力である景観評価試験の結果と出力であ る風景の構成要素との関係は, 入力を試験結果, 出力を風景とし た関係と同じ程度の因果関係があると考えられる。したがって, 本研究では, 風景を出力としたシステムは, そのネットワークが 単純であることを考慮して, 風景の構成要素出力としたシステム より優れているとの結論を得た。

通常のニューラルネットワークでは, 出力の值と全体の正解と の差の 2 乗和が最小，または全体の正解率が最大になるようにウ

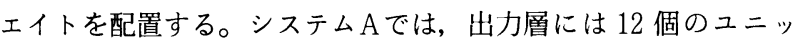
卜があるが，このうち正解が” 1 ”となるユニットは 1 個で， あ との 11 個の正解は” 0 ”である。システムの全体の正解率を評価 值とした場合正解が” 1 ”となるユニットはすべて不正解で, 正 解が” 0”となるユニットはすべて正解である時に, 正解率は $11 / 12=0.92$ と高くなる。しかし，これでは探査にならない。 また, 正解と出力值の差の 2 乗和を評価值とした場合も同様な結 果となる。本システムでは, 正解が” 1”と” 0”になる出力ユ ニットの正解率をそれぞれ計算して, 両者の逆数の和を最小にし た。この評価法を用いれば, 上記した通常の評価法に比べて正解 が” 0”となる出力の正解率は低くなるが，"1” となる出力の 正解摔は極めて高く，実際に使用できると考えられる。

遺伝的アルゴリズムによりニューラルネットワークを構築した

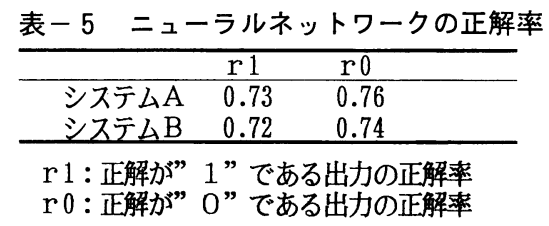

場合，上記したとおりニューラルネットワークの構造も決定でき ることおよび制約条件などを付加できることなど，バックプロパ ゲーションを用いた場合に比べて自由度が高いことが特徵である。 たとえば，システムAの評価值として正解率の逆数を用いたが, 正解率が 0 である時には評価值が無限大となり, 計算が不能とな る。遺伝的アルゴリズムでは, 評価の段階で正解率が 0 である遺 伝子を除去できるため, 支障が生じない。また，本システムでは 採用しなかったが，" 0 ”之” 1 ”の正解率の比率をある範囲に限 定することなどが可能である。

遺伝的アルゴリズムを用いた場合の短所は, 演算時間が長いこ と，および最終值が最適值か否かを判定できないことである。本 システムでは，一度に染色体 200 個体を扱い，笑変異と交差を それぞれ 500 回繰り返し, 計 20 万個体の評価を行った。したがっ て, 最終值は最適値または最適值に極めて近い值と考えられる。 システム $\mathrm{A}, \mathrm{B}$ の演算時間は，パワーマッキントッシュで，それ ぞれ約 2.5 時間および約 12 時間である。繰り返し回数を増加す れば精度が上がるため, 演算速度が速いコンピュータを用いるこ とおよび計算時間を短縮するアルゴリズムを開発することにより, 希望する風景の探査用ニューラルネットワークシステムを構築で きる。

なお，入力の形容詞対は，風景を分析するための SD 法で使用 したもの4)を用いた。実際には「醜い」または「好ましくない」 などの形容詞対を公園の来訪者が入力するとは考えられない。し たがって, 風景の探査システムに用いる形容詞対は, 風景の分析 と異なるあのを使用するべきであろう。今後, この点について検 討を進めたい。本報告を行うに当たり，貴重な助言をいただいた 筑波大学農林工学系伊藤太一先生に感謝します。

\section{参考文献}

1) 船橋誠壽 (1992)：ニューロコンピュー ティング入門 : オーム社

2) GOLDBERG, David.(1991): Gen etic algorithms in search, optimi- zation, and machine leaming.: Addison-Wesley publishing company, inc.,

3) 北野宏明 (1993)：遺伝的アルゴリズ 么 : 産業図書
4 ）市原恒一・豊川勝生・山田健 - 大川畑 修 (1994）：ヒノキ複層林の林内景観 : 造園雑誌 54(5), $191-196$

Summary : We applied neural network to develop a landscape search systems to select a forest park or a national park for visitors. At the first, autumnal forest landscapes were evaluated. Input data of the system were results of the evaluation test and output data were the landscapes, which were teaching data. Weights of the neural network were determined by a genetic algorithm. Next, we applied another network whose output data were elements of landscapes. The ratio of corrective outputs of these systems were high, because by the genetic algorithm weights of the neural network were calculated with restricted conditions and the optimum frame of the network was decided at the same time. 